\title{
Saussure and Chomsky. Langue and I-language ${ }^{1}$
}

\author{
Naoki Araki \\ Hiroshima Institute of Technology, Japan \\ araki@cc.it-hiroshima.ac.jp
}

\begin{abstract}
Ferdinand de Saussure and Noam Chomsky are considered to be the most influential linguists. In this paper, we contrast their accounts concerning the following issues of language and try to make clear differences between them, mainly referring to Saussure's langue and Chomsky's I-language: 1) How concepts emerge, 2) How phonemes appear, 3) How languages change, 4) Where syntax belongs to, 5) Whether language is social or biological, 6) What parts of speech are, and 7) Whether languages are delimited or not. By doing so, it will be understood that in what ways the two linguists have common or different ideas about language.
\end{abstract}

Keywords: langue, parole, I-language, E-language, concept, phoneme, changes of language, syntax, social fact, biology, parts of speech, delimitation of languages.

\section{Saussure y Chomsky. Lengua e I-language}

\section{Resumen}

Ferdinand de Saussure y Noam Chomsky son considerados los lingüistas más influyentes en el área. En este trabajo, contrastamos sus relatos sobre las siguientes cuestiones del lenguaje y tratamos de hacer claras diferencias entre ellas, haciendo referencia principalmente a la lengua de Saussure y a la lengua-I de Chomsky: 1) cómo surgen los conceptos, 2) cómo aparecen los fonemas, 3) cómo cambian las lenguas 4) a dónde pertenece la sintaxis, 5) si el lenguaje es social o biológico, 6) cuáles son las partes del discurso, y 7) si las lenguas están delimitadas o no. Al hacerlo, se comprenderá que de qué maneras los dos lingüistas tienen ideas comunes o diferentes sobre el lenguaje.

Palabras clave: lengua, parole (habla), lengua-I, lengua-E, concepto, fonema, cambios del lenguaje, sintaxis, hechos sociales, biología, partes del discurso, delimitación de las lenguas. 


\section{Introduction}

In the history of linguistics, Saussure and Chomsky have had a great influence on methodology of linguistics. What have they thought of language and how have they treated with language? Are their research methods or views of language the same as or different from each other? Even though their views are different, can we reconcile them? Or after all, do their views lead to the same conclusion? To answer these questions above, we will consider the two linguists' thoughts concerning languages: 1) How concepts emerge, 2) How phonemes appear, 3) How languages change, 4) Where syntax belongs to, 5) Whether language is social or biological, 6) What parts of speech are, and 7) Whether languages are delimited or not.

\section{How do concepts emerge?}

1.1. Concepts emerge after a langue divides the masses of concept and sound

According to Saussure, it is after a langue (language) divides both the mass of concept and the mass of sound at the same time that signes (words) begin to exist. This means that we have nothing dis $\rightarrow$ tinct both in the mass of concept and in the mass of sound in advance of a langue:

Psychologically, what are our ideas, apart from our language [langue]? They probably do not exist. Or in a form that may be described as amorphous. We should probably be unable, according to philosophers and linguists, to distinguish two ideas clearly without the help of a language [langue] (internal language [langue] naturally). Consequently, in itself, the purely conceptual mass of our ideas, the mass separated from the language [langue], is like a kind of shapeless nebula, in which it is impossible to distinguish anything initially. The same goes, then, for the language [langue]: the different ideas represent nothing pre-existing. There are no: a) ideas already established and quite distinct from one another, b) signs for these ideas. But there is nothing at all distinct in thought before the linguistic sign. This is the main thing. On the other hand, it is also worth asking if, beside this entirely indistinct realm of ideas, the realm of sound offers in advance quite distinct ideas (taken in itself apart from the idea). There are no distinct units of sound either, delimited in advance. [...] It would above all be necessary that the signified element should be something determined in advance, and it is not. (Saussure 1993: 137a-139a)

Does anything like "pure concepts" or "pure phonemes" exist before signes come into being? If "pure concepts" existed before signes emerge, what would happen? As proof of this, Saussure insists that his view can be verified in vocabulary, tense, and aspect:

If ideas were predetermined in the human mind before being linguistic values, one thing that would necessarily happen is that terms would correspond exactly as between one language [langue] and another.

$\begin{array}{ll}\text { French } & \text { German } \\ \text { cher [ 'dear' ] } & \text { lieb, teuer (also moral) } \\ \text { There is no exact correspondence. } & \begin{array}{ll}\text { juger, estimer } & \text { urteilen, erachten } \\ \text { [ 'judge, estimate' ] } & \text { have a set of meanings } \\ & \text { only partly coinciding } \\ & \text { with French juger, estimer }\end{array}\end{array}$

We see that in advance of the language [langue] there is nothing which is the notion 'cher' in itself. [...] Idea of different tenses, which seems quite natural to us, is quite alien to certain languages. As in the Semitic system (Hebrew) there is no distinction, as between present, future and past; that is to say these ideas of tense are not predetermined, but exist only as values in one language [langue] or another. Old German has no future, no proper form for the future. It expresses it by means of the present. But this is a matter of speaking. Hence Old German present value is not the same as in French future. Similarly if we take the difference between the perfective aspect of the verb and the imperfective aspect in the Slavic languages (difficulty in the study of these languages). In Slavic languages, constant distinction between aspects of the verb: action outside any question of time or in process of accomplishment. We find 
these distinctions difficult because the categories are unfamiliar. So not predetermined, but value. (Saussure 1993: 139a-140a)

According to Trask, Chinese lacks tense entirely and the African language BamilekeDschang distinguishes 11 tenses (Trask 2007: 294). Sampson also points out the same thing as this concerning "mood," quoting examples of French and English (Sampson 1980: 39). If Saussure is right, we cannot have what are called "pure concepts", which Chomsky thinks are innate as we shall see later, before we have acquired a language (langue). Languages are, for Saussure, a fait social (social fact). Moreover, Saussure insists that concepts separated from sounds are just an object of psychology, but not that of linguistics:

The same thing must be said as regards the mental side of the linguistic sign. If you consider the various concepts (love, see, house) in themselves, apart from their representation a representing sign, they are a series of psychological objects. In the psychological domain, you can say that it is a complex unit. The concept must be only the value of an acoustic image if it is to belong to the linguistic domain. Or else, if you bring it into the linguistic domain, it is an abstraction. (Saussure 1993: 79a)

Saussure's view leads to the denial of Chomsky's idea that we are born with concepts which are equivalent to Saussure's signifies (concepts) and are separated from signifiants (sounds). Then, why does Chomsky think that we are born with concepts? Next, we discuss Chomsky's view of concepts.

\subsection{We are born with a list of pre-existing concepts}

According to Chomsky, the properties of the Spanish words seguir, perseguir, and persuadir are very complicated:

Consider the words seguir ("follow") and perseguir ("chase"). The latter involves human intention. To chase someone is not merely to follow him; in facts, one may chase someone without exactly following his path, and one may be following someone's path precisely at a fixed distance from him without chasing him [ ] Rather, to chase someone is to follow him [ ] with a certain intention: the intention to keep on his trail and perhaps [...] to catch him. Similarly, the word persuadir ("persuade") involves the notion of causation as well as the notion of intention or decision [...]. To persuade John to go to college is to cause John to decide or intend to go to college; if John at no point decides or intends to go to college, then I have not persuaded him to go to college, however much I may have tried. The situation is in fact a good bit more complex. I may cause John to decide to go to college by force or threat, but without having persuaded him to go to college, strictly speaking. Persuasion involves volition. If I say that the police interrogator persuaded John to confess by the threat of torture, I am using the term "persuade" ironically. (Chomsky 1988: 3132)

In spite of these facts, children can learn the words perfectly right away. This means that they are born with a long list of concepts, which correspond to the words prior to any experience. Then they learn the labels that go with the preexisting concepts. Chomsky insists that this is the way children acquire their vocabulary. So, if Chomsky is right, it does not follow that we have nothing like "pure concepts" in advance of a langue as Saussure insists. But on the other hand, Chomsky does not deny that "words may not match precisely across languages (Chomsky 1988: 32)" just as Saussure has already pointed out above. In other words, he accepts the possibility of modification of the conceptual framework "by experience and varying cultural contexts (Chomsky 1988: 32)", but nevertheless he insists that the framework is a common human property:

[...] it is beyond question that acquisition of vocabulary is guided by a rich and invariant conceptual system, which is prior to any experience. (Chomsky 1988: 32)

So, for Chomsky language is a matter of biology, but not a matter of society as Saussure insists. Incidentally, Chomsky thinks that we 
are born with Universal Grammar (henceforth UG) with parameters. Then, as we are exposed to a language spoken around us, the parameters are set one way or another and we acquire a particular language. Chomsky calls this language an internalized language (I-language).

The language may be English or Japanese or whatever, depending on the circumstances under which we are living. Can't we apply this idea to acquisition of vocabulary? Suppose we are equipped with UG of concepts and sounds of words. This UG has parameters both for concepts and for sounds each. As we are exposed to words of a language, the parameters are set one way or another and we acquire a sys $\neg$ tem of concepts and sounds of the language. Chom $\urcorner$ sky has not proposed such an idea but he implies that we may have UG of morals (Chomsky 1988: 152153), the arts (Chomsky 1980: 252; 1988: 152), mathematics (Chomsky 1980: 249), face-recognition (Chomsky 1980: 248249), and science-forming capacity (Chomsky 1980: 251-252; 1988: 156-159). So it is thought that he is likely to accept the speculation above. If this hypothesis is assumed to be correct, we can explain both why children can learn words so fast and accurately and why every human language has its own unique, distinct system of concepts and sounds. Can this idea reconcile Saussure's thought that a langue determines its sounds and concepts with Chomsky's that we are equipped with concepts at birth?

\section{How do phonemes appear?}

\subsection{We are born with phonemes}

According to Chomsky, we are born with phonemes:

Consider, for example, the words listed below, where column I is the conventional orthography, column II appears

$\begin{array}{lll}\text { I } & \text { II } & \text { III } \\ \text { bet } & \text { bet } & \text { bet } \\ \text { bent } & \text { bent } & \text { bet } \\ \text { bend } & \text { bend } & \text { bend } \\ \text { knot } & \text { nat } & \text { nat } \\ \text { nod } & \text { nad } & \text { nAd }\end{array}$

$\begin{array}{lll}\text { write } & \text { rayt } & \text { rayt } \\ \text { ride } & \text { rayd } & \text { rAyd } \\ \text { writer } & \text { rayt }+r & \text { rayDr } \\ \text { rider } & \text { rayd }+r & \text { rAyDr }\end{array}$

to be the correct phonological representation, and column III, the approximate phonetic representations in one dialect of English, [...] The representations of column II are essentially the mental representations of the lexicon, which enter into the syntax and semantics. The phonetic representations of column III derive from these by straightforward rules, most of them quite general: Vowels assume a particular quality before voiced and unvoiced consonants and become nasalized before nasal consonants, the nasal consonant drops before an unvoiced dental, and (in this dialect) the dental stops merge as [D] medially under this stress contour. Applying these rules, we derive the phonetic forms (III) from the lexicalpho-nological representations (II). The latter representations are not derived from the speech sounds by analytic procedures of segmentation, classification, extraction of physical features, and so forth, but are established and justified as part of the best theory for accounting ultimately for the general relation between sound and meaning of the I-language. Further syntactic and semantic rules apply to the representations of (II) in the expressions in which these words appear. The I-language, incorporating the rules that form the representations (II) and the rules that relate them to (III), is acquired by the child by applying the principles incorporated in the initial state So [UG] to the presented facts; the problem for the grammarian is to discover these principles and show how they lead to the choice of the representations (II) [...]. (Chomsky 1986: 41-43)

Here Chomsky thinks that phonemes are innate. He says that the representations of column II (which is thought to be the phonological representation) are essentially the mental representations of the lexicon, from which the phonetic representations of column III derive. In other words, he thinks that the phonetic forms (III) are derived from the lexical-phonological representations (II). Moreover, he goes on to say, 
"the I-language, incorporating the rules that form the representations (II) and the rules that relate them to (III), is acquired by the child by applying the principles incorporated in the initial state $S_{\text {o }}$ [UG] to the presented facts". So for Chomsky, the problem for the grammarian is to discover these principles (which are incorporated in the initial state $S_{\mathrm{o}}[\mathrm{UG}]$ ) and show how they lead to the choice of the representations (II). Chomsky's explanation could be interpreted as follows:

Column II is the mental representations of the lexicon, from which the physical representations of column III derive. This means that (III) is developed from (II). How is column II acquired? Children are born with UG, which incorporates principles, and then they are exposed to the presented facts and they acquire the I-language, which incorporates both the rules that form the representations (II) and the rules that relate them to (III). So the acquisition of the representations of (II) is a matter of choice for Chomsky. It depends on what kinds of presented facts children are exposed to that they acquire what kinds of representation (II). In short, children ac-quire phonemes based on UG. After all Chomsky insists that we have phonemes and rules in advance, then we produce sounds of words, using the phonemes and applying the rules to them. For Chomsky, phonemes exist independently of concepts, which Saussure thinks are closely linked with sounds.

2.2. Phonemes appear after a langue divides the masses of concept and sound

According to Saussure we have signes after both the mass of concept and the mass of sound are divided by a langue at the same time. If something like "pure phonemes" existed in advance before signes appear, what would happen? Phonemes across all the languages would probably correspond to one another, even if in part. But they actually don't. For example, in English a phoneme $/ \mathrm{p} /$ can be pronounced $\left[\mathrm{p}^{\mathrm{h}}\right.$ ] or [p] as an allophone. But Mandarin Chinese has two different words pronounced $\left[\mathrm{p}^{\mathrm{h}} \mathrm{a}\right]$ and [pa] respectively. These two sounds $\left[\mathrm{p}^{\mathrm{h}}\right]$ and $[\mathrm{p}]$ belong to two clearly different phonemes $/ \mathrm{p}^{\mathrm{h}} /$ and $/ \mathrm{p} /$. So Mandarin Chinese has two phonemes
$/ \mathrm{p}^{\mathrm{h}} /$ and $/ \mathrm{p} /$ (Trask 2007: 214). This means that one phoneme $/ \mathrm{p} /$ in English is treated as two phonemes $/ \mathrm{p}^{\mathrm{h}} / \mathrm{p}$ and $/ \mathrm{p} /$ in Mandarin Chinese. Sampson also points out the same thing as this, quoting two examples: one is one phoneme for English and two phonemes for Russian, and the other is one phoneme for Japanese and two phonemes for English. (Sampson 1980: 38-39). So if this is true, something like "pure phonemes", which Chomsky thinks are innate, does not exist in advance:

The precautions to be taken are various, in accordance with the actual nature of the linguistic object. The first condition to be satisfied for identifying a linguistic entity is that the association between the two elements [the concept and the acoustic image] should be present and maintained. If we unwittingly take only one of the elements, one of the parts, we have straight away created a spurious linguistic unit. We have made an abstraction and it is no longer the concrete object that we have before us. One must not dissociate what is associated in the linguistic sign. (Saussure 1993: 79a)

Saussure insists that sounds fall within linguistics only when they are considered as the material basis for the concepts:

It constantly happens that in reality you take just one part of the linguistic sign even when you think you are dealing with the whole, and then you are no longer dealing with linguistic entities. Thus if we take the material side, the sequence of sounds, it will be linguistic only if considered as the material basis for the idea; but envisaged in itself (the material side) it is a substance which is not linguistic, substance which can only be relevant to the study of speech, if the envelope of the word represents a substance which is not linguistic. A language we do not know is not linguistic as far as we are concerned. From that point of view, you can say that the material word is an abstraction from the linguistic point of view. As a concrete object, it is not part of linguistics. (Saussure 1993: 79a)

Similarly, for Saussure, both sounds and concepts are closely linked together, so neither 
sounds separated from concepts nor concepts separated from sound sare theobject of linguistics, but that of phonetics or psychology respectively. For Chomsky, we are born with concepts and phonemes and find out sounds which are to be combined with the concepts. Then we produce the sounds, using the phonemes and applying rules, which are innate, to them. According to Saussure, neither concepts separated from sounds, nor sounds separated from concepts are objects of linguistics and do exist in advance of a langue in itself. In this respect, Saussure and Chomsky are sharply opposed to each other. By the way, Sampson is skeptical of the reality of phonemes, quoting an example of Mandarin Chinese (Sampson 1980: 70-74). He says that the phoneme theory is just a statistical tendency.

\section{How do languages change?}

\subsection{Parole changes langue}

Saussure says that it is parole that changes a langue:

But changes always begin with facts of speech [parole]. [...] Every evolution, every evolutionary fact in a language [langue] begins with a fact of speech. [...] The cause of evolutionary linguistic facts lies in facts of speech. [...] But at the same time, it will be seen that the facts of speech where an innovation is tried out are always individual. Why in German did people come to say ich war-wir waren instead of ich was- wir waren (as in English I was: we were)? Because a few individuals began to say ich war by analogy. It was only a fact of speech [parole] and not a fact of the language [langue] as long as there were only a few individuals who did it. (Saussure 1993: 118a-119a)

Thus, it is not until a society accepts parole that parole has become a part of a langue. So it follows that a langue does not precede parole, but that parole causes historical changes of a langue. Moreover, the changes are caused by "analogy".

3.2. Historical changes oflanguages are consequences of re-settings of parameters
On the other hand, Chomsky insists that historical changes of an E-language (externalized language), which is equivalent to parole in Saussure's framework, are caused by re-settings of parameters of UG:

In Spanish, for example, there are such constructions as

a. Llega.

Arrives.

"He/she/it arrives".

b. Llega Juan.

Arrives Juan.

"Juan arrives".

[...] The same is true of Italian and other Romance languages. But in French the corresponding forms are impossible. The subject must be explicitly expressed throughout, and it cannot follow the verb as in (23b) [...] These differences between French and the other Romance languages developed only a few centuries ago and apparently at about the same time. It is likely that they are consequences of a change in a single parameter, perhaps influenced by the example of the nearby Germanic languages. [...] Some progress has been made in reducing these consequences to what is called the null subject parameter, which determines whether the subject of a clause can be suppressed, as in (23a), [...] (Chomsky 1988: 63-64)

As we have seen, Chomsky thinks that historical changes of an E-language are caused by re-settings of parameters of UG while Saussure insists that changes of parole, which is equivalent to an E-language, cause those of a langue, which is thought to be equivalent to an I-language. Here the point may be the interpretation of Saussure's idea of "langue". Saussure asks why people say in German, "ich war -wir waren", but not "ich was -wir waren" as in English "I was- we were". He answers, "Because a few individuals began to say ich war by analogy". So here Saussure treats with the change of vocabulary, in this case, from "was" to "war", but not the change of word order as in the case of French illustrated by Chomsky. It may be the logical necessity that Saussure's example of change of language is limited to vocabulary 
because his langue excludes sentences from its domain as we shall see later. On the other hand, for Chomsky the change of language means that of word order because his parameters of UG are not thought to be involved in vocabulary at all. So the difference between Saussure and Chomsky on the changes of language may not be discussed in the same way. For Saussure a langue is an inventory of words while for Chomsky an I-language is the con-sequences of UG with parameters set in a particular manner. So changes of a langue are, for Saussure, changes of vocabulary whereas changes of an I-language are, for Chomsky, changes of parameters of UG because an I-language is consequences of UG after parameters are set in a particular way. So it seems that these two theories are not compatible with each other. But if Saussure's theory is interpreted as the following: parole changes the values of parameters of UG, and then a langue also changes, this interpretation may coincide with Chomsky's theory quite well. After all, do Saussure and Chomsky explain the same phenomena in a different way?

\section{Where does syntax belong to?}

\subsection{Syntax belongs to parole}

According to Saussure, valeurs (values) of words are realized by the opposition or difference between words. This opposition or difference is developed in two domains, one of which is called a syntagmatic relation (a syntagma):

The value (valeur) of a word at any given moment exists only in relation to other similar units. The relation and the difference between words has its basis in two dimensions, two quite separate domains: each of these generates a certain kind of value and the contrast between the two itself throws light on each. We are dealing with two domains or two ways of connecting words with one another. There is 1) syntagmatic coordination and the domain of syntagmatic relations. [...] This combination giving rise to certain relations may be called a syntagma. It is the combination of two or several units, all present and consecutive. If they formed a sequence with no connexion between them, I would not call them a syntagma, but several consecutive units with a connexion between them or with the whole form a syntagma. (Saussure 1993: 128a-129a)

As "the combination of two or several units", for example, we have a German word Hauptmann, a German compound word Dummheit, a Latin word magnanimus (and animus as well), and a French fixed expression (cliché) s'il vows plait in each langue. Then do sentences, which are combinations of words called syntagmas, belong to a langue? Saussure answers this question:

Syntagmas, although they are to be seen in combinations that are not sentences, clearly include sentences themselves as types. Every sentence will be a syntagma. Now the sentence belongs to speech [parole] and not to the language [langue]. (Saussure 1993: 131a)

Furthermore, Saussure explains why sentences belong to parole and not to a langue:

[...] there is always that individual element, the combination which is left for everyone to choose in order to express their own thought in a sentence. This combination belongs to speech [parole], for it is an execution.(Saussure 1993: 73a)

Thus, Saussure cannot help admitting that a syntagmatic relation (a syntagma) belongs both to a langue and to parole:

That part (second individual use of the language code) raises a question. It is only ultimately in syntax that there is a certain vagueness about what is given in the language [langue] and what is left to individual initiative. The delimitation is difficult to establish. It must be admitted that here in the domain of syntax the social element [langue] and the individual element [parole], execution and fixed association, are somewhat intermingled, get more or less intermingled. (Saussure 1993: 73a)

\subsection{Syntax belongs to I-language}

According to Chomsky, we have "notion of structure" in our mind, which he calls an "internalized language (I-language)": 
[...] Otto Jespersen, who held that there is some "notion of structure" in the mind of the speaker "which is definite enough to guide him in framing sentences of his own," in particular, "free expressions" that may be new to the speaker and to others. Let us refer to this "notion of structure" as an "internalized language" (I-language). The I-language, then, is some element of the mind of the person who knows the language, acquired by the learner, and used by the speaker-hearer. (Chomsky 1986: 21-22)

We acquire an I-language after parameters of UG are set one way or another, depending on the language spoken around us. Moreover, this UG has certain categories of lexical items:

Universal grammar permits certain categories of lexical items, basically four: verbs $(\mathrm{V})$, nouns (N), adjectives (A), and adpositions $(\mathrm{P}$; prepositions or postpositions, depending on whether they precede or follow their complements). [...] For each of these basic categories, universal grammar provides a projection of which it is the head: verb phrase (VP), noun phrase (NP), adjective phrase (AP), adpositional phrase (PP). (Chomsky 1988: 68)

Each projection is composed of a head and a complement. Chomsky thinks that it is determined by a parameter of UG called a headparameter whether a head precedes or follows a complement. For example, in Spanish, the value of the head-parameter is "head first," which means heads precede complements in the four projections:
a. VP: hablar inglés "speak English"
b. NP: traducción del libro
translation of-the book
"translation of the book"
c. AP: lleno de agua
"full of water"
d. PP: a Juan
"to Juan"
(Chomsky 1988: 68)

The same is true of English too. But in Miskito and Japanese, the value of the head-parameter is "head last," which means heads follow complements in the four projections. Chomsky's explanation seems to be perfect but there are some languages whose word order cannot be explained using the head-parameter of UG:

There are possibilities of word order permitted by universal grammar that go beyond those I have illustrated. The languages mentioned so far observe the condition that the elements of a phrase are adjacent, [...] But some languages do not observe this condition of adjacency in the underlying abstract structure. Phrases may be genuinely "scattered", though there is good reason to believe that the phrases do exist and are determined by the same general principles with other forms of association replacing adjacency. (Chomsky 1988: 73)

Thus, Chomsky manages to solve the problem of word order based on the head-parameter of UG. On the other hand, Saussure thinks that sentences, which appear as a syntagmatic relation, belong to parole, but not to a langue. So word order, such "head first" or "head last" as Chomsky insists, does not belong to a langue. This means that Chomsky's assertion is not the subject matter of linguistics for Saussure. "Notion of structure," which Jespersen thinks is necessary in making sentences of "free expressions," belongs to parole according to Saussure. Thus syntax, which is the main theme for Chomsky, belongs to parole for Saussure. Should Saussure have limited syntagmatic relations to parole? Why does not Saussure think that sentences belong to a langue? The number of sentences is infinite So if we suppose that sentences belong to a langue, then it follows that in a langue we have all the sentences we make in prior to actual utterances. This means that we derive the suitable ready-made sentences from a langue. This comes to mean that uttering sentences is not a creative activity. Saussure might have wanted to avoid such a conclusion. Sampson says almost the same thing as this (Sampson 1980: 54). On the other hand, Chomsky seeks formal universality, admitting the infinity of linguistic expressions. He assumes UG to be innate in human beings because children can acquire a complexly structured language easily and quickly without being taught anything. His 
head-parameter is postulated as a mechanism to enable various human languages to be derived from UG. But actually even in English, which has a relatively fixed word order, an object could be moved before a verb: This paper I have written. Is Chomsky really right? Is word order determined by a parameter of UG? As we have seen, Saussure regards sentences as an individual execution while Chomsky insists that word order is biologically determined by the value of the head-parameter of UG. After all, the question of where sentences belong to may be a matter of what a langue or I-language is. For Saussure, a langue is an inventory of words so it follows that sentences belong to parole, but not to a langue. On the other hand, for Chomsky, an I-language is consequences of parametersetting of UG, so sentences, in this case, types of word order, belong to an I-language, but not to an E-language. Their difference concerning sentences may come from that between a langue and an I-language.

\section{Is language social or biological?}

\subsection{Langue is a social fact (fait social)}

According to Saussure, a langue exists as what is socially approved by members of a community. It is located in brains of members of a community just like a dictionary. Moreover, a langue exists as if it were outside of the will of members of a community:

Developing and fixing this product [langue] is the work of the collective intelligence. Everything that is the language [langue] is implicitly collective.

Whereas there is no collective speech [parole]. To say that a word has come into the language [langue] is to say that it has received collective approval. Acts of speech [parole] remain individual, apart from being momentary. Crowd gathered in a market square; in what way is the language [langue] present in this crowd? In the form of a deposit existing in brain of each of the persons making up the crowd like a dictionary of which all the copies were distributed to these persons. This thing, although internal to each individual, is at the same time collective, lying beyond the will of the individual. $1+1+1=1$ (collective model). (Saussure 1993: 91a)

A langue is what is acquired but not an ability endowed by nature:

[...] The language faculty, it will be said, appears to us as a faculty given to us by nature, whereas the language [langue], on the contrary, is something that is acquired and conventional. It cannot take precedence over natural phenomena, natural instincts. (Saussure 1993: 66a)

Furthermore, Saussure compares a langue to work of music:

The language [langue] is comparable to work of music. A musical work exists only in virtue of the total number of performances of it. The performances are something quite apart from the work. A symphony is a reality that exists without any performance. Similarly, the renderings in speech [parole] of what is given in the language [langue] may seem inessential. (Saussure 1993: 72a)

As we have seen, langue is a social fact for Saussure.

\subsection{I-language is biological}

According to Chomsky, on the other hand, I-language is mental states and representations of the mind/brains, which is physically encoded in some manner. Moreover, I-language is the human biological endowment, so linguistics is ultimately part of biology:

[...], the steady state of knowledge attained [I-language] and the initial state $S_{\mathrm{o}}[\mathrm{UG}]$ are real ele $\neg$ ments of particular mind/brains, aspects of the physical world, where we understand mental states and representations to be physically encoded in some manner. [...] Linguistics, conceived as the study of I-language and So [UG], becomes part of psychology, ultimately biology. (Chomsky 1986: 26-27) 
For Chomsky, an I-language exists in the brain of a single individual, even though there are not any other people. But for Saussure, a langue does not exist as a perfect thing in a single individual as Chomsky asserts. It is not until there are many individuals who consist of a society that a langue does exist. For Chomsky, an I-language is physical but for Saussure, a langue exists outside of an individual's will. Chomsky insists that an I-language, which is acquired after parameters of UG are set one way or another, is innate and endowed by nature whereas Saussure thinks that a langue is what is learned. In this respect, Chomsky's I-language is biological but Saussure's langue is social. Saussure says that a langue exists without the execution of parole just as work of music does without being performed. Similarly, Chomsky thinks that the essence of chess is not the moves of its pieces but its rules (Chomsky 1986: 27). This means that the essence of language is not utterances made in everyday life (E-language) but what enables such utterances (I-language). As we have seen, Saussure and Chomsky agree that the essence of language is language rules which intervene between cognition and expression, whether a language is thought to be social or biological. But if language rules are, as Miura points out (Miura 1967: 149-199), "conceptually objectified will" which intervenes between cognition and expression in process structure of language: object cognition-' expression, it is thought that Chomsky reduces language rules to physical things and Saussure thinks of them as something like a dictionary. Why does Saussure think that a langue is social (a fait social)? Why does Chomsky think that an I-language is biological? It may be because Saussure's langue is based on the social contract and Chomsky's I-language is derived from UG, which is biologically determined in genes.

\section{What are parts of speech?}

6.1. Parts of speech are innate and physically encoded in the mind/brains

Chomsky's UG has four categories of lexical items:
Universal grammar permits certain categories of lexical items, basically four: verbs $(\mathrm{V})$, nouns (N), adjectives (A), and adpositions (P; prepositions or postpositions, depending on whether they precede or follow their complements). [...] The basic elements of the lexicon fall within these four categories, [...] (Chomsky 1988: 68)

We acquire various I-languages (human languages) after the values of the parameters of UG are set one way or another. So it is thought that four categories: verbs $(\mathrm{V})$, nouns $(\mathrm{N})$, adjectives (A), and adpositions (P) are innate, common and universal across all the human languages.

\subsection{Parts of speech are not a linguistic reality}

On the other hand, for Saussure the classification of parts of speech is not a grammatical reality:

In the French sentence ces gants sont bon marche ('these gloves are good value'), is bon marche ('good value') an adjective? Logically, it has the right meaning. But grammatically it is less clear. For bon marche does not behave like a normal French adjective: it is invariable, never precedes its noun, and so on. Furthermore, it consists of two words. What the parts of speech provide is a classification of individual words: so how can a group of two words belong to one or other of the parts of speech? Yet if we split it up into two words, and say bon ('good') is an adjective, whereas marche ('value' ) is a noun, we have not accounted for the single expression bon marche ('good value'). The conclusion is that our 'parts of speech' classification must be defective or incomplete: its division of words into nouns, verbs, adjectives, etc. does not correspond to any undeniable linguistic reality. (Saussure 1983: 108)

The same thing may be true of a piece of cake in the English sentence "The question is a piece of cake". Is it an adjective? It never has the comparative or superlative degree. Furthermore, it consists of four words. So how can a group of four words belong to one or other of the parts of speech? Yet if we split it up into four words, and say a 
is an article, piece a noun, of a preposition, and cake a noun, we have not accounted for the single expression a piece of cake. Chomsky is sharply opposed to Saussure in regard to classification of parts of speech. For Chomsky, parts of speech are physical and biologically encoded in genes, but for Saussure, they are not grammatical reality but what is logical (we mistake parts of speech for what is grammatical). Are parts of speech innate or just logical artifacts? It is unlikely that Saussure would accept Chomsky's reality of parts of speech because he thinks that parts of speech are logic and imposed on grammar. After all, for Saussure, a langue is concerned with only words (signes). So parts of speech are not involved in a langue but in logic as he suggests. On the other hand, for Chomsky, an I-language is concerned with word order, or syntax. So the distinction of "parts of speech" is closely linked with an I-language because the distinction of "parts of speech" is indispensable to word order, or syntax. So their difference in regard to "parts of speech" is due to that between their key concept of language: langue and I-language.

\section{Is langue or I-language delimited?}

\section{1. I-language is delimited}

According to Chomsky, the term "language" involves obscure sociopolitical factors:

We speak of Chinese as a language, whereas Spanish, Catalan, Portuguese, Italian, and the other Romance languages are different languages. But the so-called dialects of Chinese are as varied as the Romance languages. We call Dutch a language and German a different language, but the variety of German spoken near the Dutch border can be understood by speakers of Dutch who live nearby, though not by speakers of German in more remote areas. (Chomsky 1988: 37)

So Chomsky asserts that the term "language" is not useful in linguistics because of its sociopolitical factors.

\subsection{Langue is not delimited}

On the other hand, according to Saussure, there are no boundaries between langues:

On the same principle by which languages [langues] are divided into dialects, there are no precise boundaries between languages [langues]. 1) Supposing there were a uniform language [langue] $\mathrm{A}$ and an equally uniform language [langue] $\mathrm{B}$, the presence of a transition zone would be surprising. But language [langue] $\mathrm{A}$ is an aggregate of dialects internally related, while language [langue] $\mathrm{B}$ is likewise an aggregate of dialects. Everything is transitional from one end of the area to the other. 2) In the schema I have just presented, I assumed dialects to be closed; but ultimately there are only dialects open on all sides, formed by the succession of waves in which they participate. We must not imagine there are boundaries between language [langue] A and language [langue] B. (Saussure 1993: 31a)

For Saussure, a langue is a continuum with no boundaries between langues. Chomsky insists that an I-language, which is acquired after the values of parameters of UG are set one way or another, is the object of linguistics because a language, which is called an E-language by Chomsky, has a vague sociopolitical factors. On the other hand, Saussure does not admit the boundaries of languages [langues] at all. But there are boundaries between I-languages because each I-language is the consequences of a particular parameter-setting of UG. I-languages are different from one another in the values of parameters. But langues have no boundaries between themselves. So is it impossible that Chomsky's I-language and Saussure's langue can be reconciled? When Chomsky asserts that the term "language" involves obscure sociopolitical factors, he refers to E-language as language. So for Chomsky, I-language does not involve any obscure sociopolitical factors at all, but it is a clear and scientific object of linguistics. On the other hand, for Saussure, there are no boundaries between langues. So it follows that there are no boundaries whatever between paroles, which are nothing but executions of langues. That is to say, for Saussure, there are no boundaries both 
between langues and between paroles. Saussure and Chomsky agree that the term "language" (E-language) involves obscure sociopolitical factors and there are no boundaries between paroles, which are execution of langues. But they do not agree that an I-language is a delimited entity defined by the values of parameters of UG but that there are no boundaries whatever between langues, which are thought to be equivalent to I-languages in Chomsky's framework. After all, can't we reconcile these two theses: 1) Saussure's thesis that there are no boundaries at all between langues; and 2) Chomsky's thesis that I-languages are delimited entities, which can be studied in the scientific framework as in other domains of natural sciences? For Saussure, a langue is, after all, the consequences of how the world, which is a continuum according to him, is split into a certain pattern, which is a langue itself. So there could be overlaps between langues, which are not the same as one another. That's why Saussure says that there is no boundaries between langues. On the other hand, for Chomsky, E-languages, considered as something social, do not have any inherent boundaries between themselves as Saussure asserts, but I-languages, considered as consequences of parameter-settings of UG, have a definite boundaries between themselves. This difference may be also based on that of their views of language: langue and I-language.

\section{Conclusion}

We have considered Saussure's and Chomsky's views of languages. What underlies their differences is their fundamental idea of languages. Saussure insists that languages are a social fact while Chomsky asserts that languages are biological. Their different views of language come from these basic standpoints. Although Saussure and Chomsky have had a great impact on linguistics and other fields of sciences as well, their thoughts on language have never been unified into one grand theory so far, just as the theory of relativity and the quantum theory have not. Will these two thoughts be reconciled some day? Or will one of the two give way to the other?

\section{References}

Chomsky, Noam. Rules and Representations. Columbia University Press. 1980.

Chomsky, Noam. Knowledge of Language: Its Nature, Origin, and Use. Praeger. 1986.

Chomsky, Noam. Language and Problems of Knowledge. The MIT Press. 1988.

Miura, Tsutomu. Theory of Cognition and Language: Part 1. Keisoshobo. 1967. (in Japanese)

Sampson, Geoffrey. Schools of Linguistics. Stanford University Press. 1980.

Saussure, Ferdinand de. Course in General Linguistics (edited by Charles Bally and Albert Sechehaye with the collaboration of Albert Riedlinger, translated and annotated by Roy Harris). Duckworth. 1983.

Saussure, Ferdinand de. Troisieme Cours de Linguistique General (1910-1911) d'apres les cahiers d'Emile Constantin (Saussure's Third Course of Lectures on General Linguistics (1910-1911) From the notebooks of Emile Constantin, French text edited by Eisuke Komatsu, English translation by Roy Harris). Pergamon Press. 1993.

Trask, R.L. Language and Linguistics, the Key Concepts. 2nd edition. Routledge. 2007. 